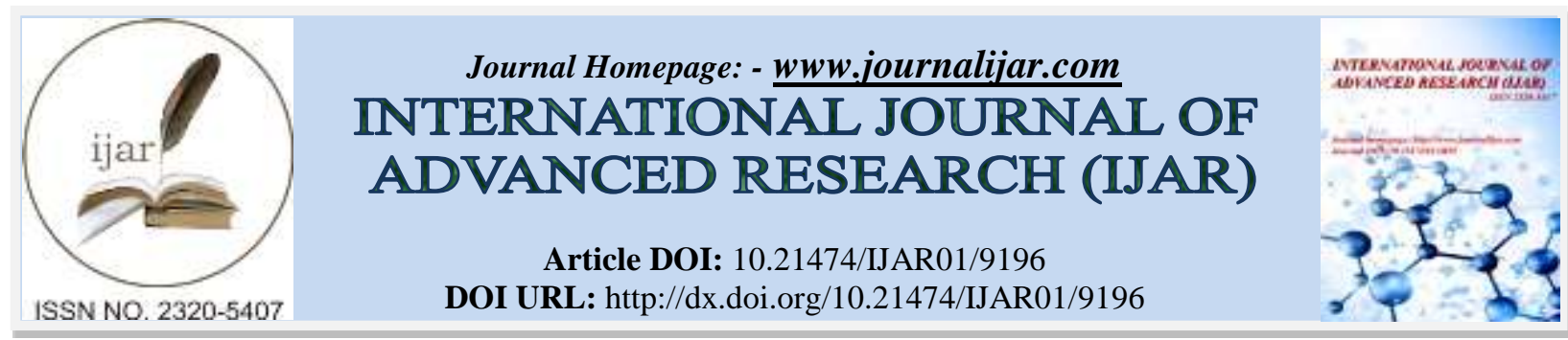

RESEARCH ARTICLE

\title{
EFFECT OF BENOMYL SPRAY PROGRAM ON DEVELOPMENT OF BENOMYL RESISTANCE IN FUSARIUM OXYSPORUM F. CONGLUTINANS CAUSING YELLOWS OF KOHLRABI.
}

\author{
M. A. Sutar and S. S. Kamble.
}

Mycology and Plant Pathology, Research Laboratory, Department of Botany, Shivaji University, Kolhapur.

\section{Manuscript Info}

Manuscript History

Received: 03 November 2017

Final Accepted: 05 December 2017

Published: January 2018

\begin{abstract}
Sensitive isolate Fusarium oxysporum $f$. conglutinans cultured on benomyl continuously for eight successive passages and significantly increased the benomyl resistantance. Use of benomyl alternately with Roko, Kavach and Carbendazim completely inhibited growth of pathogen at $3^{\text {rd }}$ passage only. When benomy mixed with Roko, Kavach, Ridomil, Carbendazim growth of pathogen was completely inhibited at $2^{\text {nd }}$ passage only.
\end{abstract}

Copy Right, IJAR, 2018,. All rights reserved.

\section{Introduction:-}

Kolhrabi (Brassica oleracea var.gongylodes L.) is an important vegetable. It is a stout, round, tuberous and enlarge portion of stem .The whole plant are edible. Kohlrabi has a good amount of fat and zero cholesterol. Such important plant suffers from yellows of kohlrabi caused by Fusarium oxysporum $f$. conglutinans. Many workers has been reported resistance to systematic fungicides in certain fungi (Gangawane and Saler, 1981; More, 2009; Whaghmare, 2010). In the present investigation the effect of different passage on the development of benomyl resistance in Fusarium oxysporum f.conglutinans causing yellows of kohlrabi was studied continuously, alternatively and mixed passage with Roko, Kavach, Ridomil and carbendazim up to eight successive passages.

\section{Material and method:-}

Fourteen isolates of Kohlrabi yellows were collected from different localities of Maharashtra and Karnataka. The samples of pathogen were isolated on CDA medium and pure culture maintained at $28 \pm 2^{\circ} \mathrm{c}$ for further study. Then MIC of benomyl against the pathogen was determined. After determination of MIC of benomyl, the effect of continuous, alternate treatment of fungicides with two different fungicides having different mode of action in mixture of both on the development of benomyl resistance in sensitive isolate of Fusarium oxysporum f.conglutinans (FOC-3) was studied in in vitro.

\section{In vitro studies:-}

\section{Continuous passage:-}

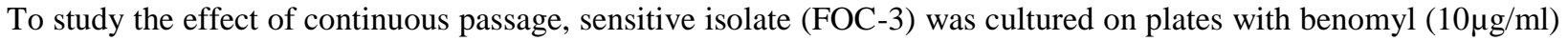
in triplicate. $8 \mathrm{~mm}$ diameter agar disc from the previous passage of the same isolate was placed at the center of each plate of next passage. In each passage, linear growth was measured after 6 days. This was repeated up to 8 passages.

\section{Alternate passage:-}

To study the effect of alternate passage, sensitive isolate (FOC-3) was cultured on plates containing benomyl with another fungicide, both having equal concentration $(10 \mu \mathrm{g} / \mathrm{ml})$ and $8 \mathrm{~mm}$ diameter agar disc of fungal culture from the previous passage was transferred to the plate containing same proportion and same concentration. 


\section{Mixed passage:-}

To study the effect of mixed passage on benomyl resistance the wild sensitive isolate (FOC-3) was cultured on plates with benomyl with another fungicide both having equal proportion and concentration $(10 \mu \mathrm{g} / \mathrm{ml})$. An $8 \mathrm{~mm}$ diameter agar disc of fungal culture from the previous passage was transferred on plate with same concentration.

\section{Result and Disscution:-}

Culturing of the sensitive Fusarium oxysporum f. conglutinans isolate (FOC-3) on continuously increased benomyl resistance. Use of benomyl alternately with Roko, Kavach and Carbendazim completely inhibited the growth of pathogen at third passage only. When benomyl was mixed with Roko, Kavach, Ridomyl and Carbendazim, the growth of pathogen was completely inhibited at second passage only. Horsten, (1979) found that alternate use of ediphenphols with carbendazim controlled the growth of Septoria nodurum and Cercosporella herpotrichadis. Alternate use of mancozeb with metaxyl also prevented potato plants from Phytophthora infestans inciting late blight of potato (Hartill, 1983). According to Gangawane and Shaikh (1988), treatments of aluminum ethylphosphite in mixture with ziram, copper oxychloride and mancozeb increased resistance in Pythium aphanidermatum in successive passages. But alternate treatment of these fungicides significantly reduced aluminum phosphite resistance in pathogen from passage to passage.

Table 1:- Effect of exposure of Fusarium oxysporum f.conglutinans (in vitro) benomyl continuously and alternating with other fungicide on the development of resistance during 8 passages.

\begin{tabular}{|c|c|c|c|c|c|c|c|c|c|}
\hline Fungicide & \multicolumn{9}{|c|}{ Passage numbers } \\
\hline & $\mathbf{1}$ & $\mathbf{2}$ & $\mathbf{3}$ & $\mathbf{4}$ & $\mathbf{5}$ & $\mathbf{6}$ & $\mathbf{7}$ & $\mathbf{8}$ \\
\hline Benomyl individual & 11.50 & 13.50 & 15.00 & 16.00 & 17.00 & 17.60 & 18.00 & 20.00 \\
\hline Benomyl alt.kavach & 9.50 & 13.50 & 00 & 00 & 00 & 00 & 00 & 00 \\
\hline Benomyl alt.Roko & 13.50 & 10.00 & 00 & 00 & 00 & 00 & 00 & 00 \\
\hline Benomyl alt.Ridomil & 10.50 & 32.50 & 25.00 & 11.50 & 00 & 00 & 00 & 00 \\
\hline Benomyl alt.Carbendazim & 11.5 & 12.5 & 00 & 00 & 00 & 00 & 00 & 00 \\
\hline
\end{tabular}

Mixed Passage:-

Table 2:- Effect of exposure of Fusarium oxysporum f.conglutinans (in vitro) benomyl with other fungicide on the development of resistance during 8 passages.

\begin{tabular}{|c|c|c|c|c|c|c|c|c|c|}
\hline Fungicide & \multicolumn{9}{|c|}{ Passage number } \\
\hline & $\mathbf{1}$ & $\mathbf{2}$ & $\mathbf{3}$ & $\mathbf{4}$ & $\mathbf{5}$ & $\mathbf{6}$ & $\mathbf{7}$ & $\mathbf{8}$ \\
\hline Benomyl + Roko & 31.00 & 00 & 00 & 00 & 00 & 00 & 00 & 00 \\
\hline Benomyl+Kavach & 43.00 & 00 & 00 & 00 & 00 & 00 & 00 & 00 \\
\hline Benomyl+Ridomil & 46.00 & 00 & 00 & 00 & 00 & 00 & 00 & 00 \\
\hline Benomyl+Carbendazim & 50.00 & 00 & 00 & 00 & 00 & 00 & 00 & 00 \\
\hline
\end{tabular}

\section{Referances:-}

1. Gangawane, L.V. and Saler R. S. (1981). Resistance to fungicides in Aspergillus flavus. Neth. J. Pl. Pathol. 87: 254.

2. Gangawane, L.V. and Shaikh, S.A. (1988). Development of resistance Pythium aphanidermatum to aluminium ethyl phosphate. Indian Phytopath. 41: 638-640.

3. Hartill, W. F.T. (1983) Development in New Zealand of resistance to dicarboximides fungicides in Botrytis cinerea to acylanine in phytophthora.

4. Horsten, J.A.H.M. (1979). Acquired resistance to systemic fungicides of Septoria nodorum and Cercosporella herpotrichoides in cereals. Dissertation Agricultural Univ., Wageningen, Netherlands, pp. 107.

5. More, S. B. (2009) Studies on management of soybean rust Ph.D thesis, Shivaji University, Kolhapur.

6. Waghamare, M.B. (2010), Studies on management of some important diseases of rose.Ph.D Thesis, Shivaji University, Kolhapur. 